\title{
Interdependence of vitamin $A$ and iron: an important association for programmes of anaemia control
}

\author{
BY MARTIN W. BLOEM \\ Helen Keller International/Indonesia, PO Box 4338, Jakarta, Indonesia
}

Nutritional anaemia and vitamin A deficiency are two of the most prevalent nutritional problems in the developing countries (United Nations Administrative Committee on Coordination/Subcommittee on Nutrition, 1992). Anaemia affects over one billion people, particularly women of reproductive age and preschool children in tropical and sub-tropical zones. Over $40 \%$ of all women in developing countries are anaemic, equivalent to just over $\mathbf{3 7 0}$ million women, and at least half the anaemia worldwide is due to dietary Fe deficiency (United Nations Administrative Committee on Coordination/ Subcommittee on Nutrition, 1992). Vitamin A deficiency, defined by eye signs, has been identified as a public health problem in thirty-seven countries worldwide and an estimated 190 million children are suffering from subclinical or clinical vitamin A deficiency (Humphrey et al. 1992).

Both the Montreal Meeting on Micronutrients, October 1991, and the International Conference of Nutrition in Rome, December 1992, therefore, called for all efforts to be made to eliminate deficiencies in vitamin $\mathrm{A}$ and Fe before the end of the decade (Food and Agriculture Organization/World Health Organization, 1992).

Since the study of Findlay \& MacKenzie (1922), several reports have suggested an interdependence between vitamin $\mathrm{A}$ and $\mathrm{Fe}$. This association may have many implications since sustained efficacy of Fe supplementation in programmes administered is uncommon. This is mainly due to poor compliance related to gastrointestinal sideeffects, but in areas where vitamin A deficiency is endemic Fe supplementation alone seems to be less effective than vitamin $\mathrm{A}$ and Fe supplementation combined.

The present paper will describe the various reports on the interdependence of vitamin $\mathrm{A}$ and Fe.

\section{ANIMAL STUDIES}

Findlay \& MacKenzie (1922) reported that vitamin A-deficient rats developed patches of gelatinous degeneration in their bone marrow, and that in animals which had survived longest, the haematopoietic tissue had been replaced almost completely with fibrous stroma. A subsequent study by Wolbach \& Howe (1925) did not show characteristic changes in the bone marrow, but in a few cases reduction in haematopoietic cells was apparent. Several studies have reported anaemia in vitamin A-deprived animals, but other studies have shown contradictory reports of polycythaemia instead of anaemia (Koessler et al. 1926; Sure et al. 1929; McLaren et al. 1965; Amine et al. 1970; Corey \& Hayes, 1972; O'Toole et al. 1974; Mahant \& Eaton, 1976). Severe vitamin A deficiency in rats causes imbalances in water regulation, in particular a decrease in extracellular water. This may lead to haemoconcentration as the vitamin A deficiency proceeds and this can be misinterpreted as polycythaemia (Koessler et al. 1926; McLaren et al. 1965; Mejia et al. 1979a,b; Roodenburg et al. 1994). Koessler et al. (1926) were the first to call 
attention to this phenomenon. Early in their experiment, rats developed low levels of haemoglobin and low erythrocyte counts, but as the vitamin A deficiency progressed, the animals became dehydrated and packed cell volumes and haemoglobin levels increased.

Roodenburg et al. (1994) have shown that vitamin A deficiency produced a mild anaemia as the first change in Fe metabolism in rats. This was followed by an increase in apparent $\mathrm{Fe}$ absorption and a rise in $\mathrm{Fe}$ levels in the spleen. The decrease in $\mathrm{Fe}$ mobilization, indicated by the lower total Fe-binding capacity, and the increase in $\mathrm{Fe}$ absorption may have caused the continuous increase in tissue Fe concentration observed in vitamin A-deficient rats. In the rats with Fe deficiency, low tissue Fe levels were associated with high $\mathrm{Fe}$ absorption and high total Fe-binding capacity (Roodenburg et al. 1994). In a subsequent carefully-designed study, these authors showed that in marginally vitamin A-deficient rats, vitamin A supplementation together with $\mathrm{Fe}$ is more effective in normalizing Fe status than is Fe supplementation alone (Roodenburg et al. 1995).

From these studies in animals it can be concluded that vitamin A deficiency does produce anaemia, increased $\mathrm{Fe}$ absorption, and haemosiderosis of spleen and liver, but as the deficiency progresses, the process of haemoconcentration leads to increased concentrations of haemoglobin in blood.

\section{HUMAN STUDIES}

Blackfan \& Wolbach (1933) demonstrated anaemia in vitamin A-deficient patients. The authors also observed haemosiderosis of the spleen and liver. Repletion with vitamin A was followed by regeneration of the bone marrow, disappearance of the haemosiderin from the spleen and liver, and erythroblastic activity. Wagner (1940) showed that subjects maintained on a vitamin A-deficient diet for 6 months developed low haemoglobin and packed cell volume levels, and concluded that haemopoiesis was impaired. Hodges et al. (1978) have described a study with human volunteers who received a diet very low in vitamin A for 359-771 d. Although assessment of haematological responses was not a primary objective of the study, a gradual anaemia developed several months after the beginning of the study that did not respond to medicinal $\mathrm{Fe}$. The researchers also described a decline in serum $\mathrm{Fe}$ but not in total Fe-binding capacity. After repletion with $\beta$-carotene or vitamin $A$, all patients had a prompt and complete haematological recovery.

\section{Observational studies}

Mejia et al. (1977) reviewed data from studies at INCAP and found a positive correlation between serum retinol and haemoglobin in children aged 5-12 years old. They did not find, however, a correlation between $\mathrm{Fe}$ and serum retinol in those children with an adequate intake of $\mathrm{Fe}$, classified by both dietary information and socio-economic level (Mejia et al. 1977).

Hodges et al. (1978) reviewed the statistical correlations between vitamin A nutrition and anaemia, using the results of studies by the US Interdepartmental Committee for National Defense. They selected data on non-pregnant and non-lactating women, aged $15-45$ years from regions or countries where the intake of $\mathrm{Fe}$ was $\geqslant 14 \mathrm{mg} / \mathrm{d}$, but vitamin A intake was low or marginal. There was no relationship between haemoglobin and $\mathrm{Fe}$ intake, but a strong relationship $(r 0.78, P<0.05)$ between serum vitamin $A$ and haemoglobin. 
During the last decade, several cross-sectional studies have been reported from Thailand (Bloem et al. 1989), Ethiopia (Wolde-Gebriel et al. 1993) and Indonesia (Suharno et al. 1992). Bloem et al. (1989) showed that serum retinol was significantly associated with packed cell volume $(b 0.062, P<0 \cdot 05)$, serum $\mathrm{Fe}(b 0 \cdot 172, P<0 \cdot 001)$, ferritin $(b 0.114, P<0 \cdot 001)$, transferrin $(b-0.094, P<0.001)$, and saturation of transferrin $(b 0 \cdot 192, P<0 \cdot 001)$. However, there was no correlation between haemoglobin and serum retinol (Bloem et al. 1989).

\section{Intervention studies}

Mohanram et al. (1977) reported an intervention study with daily oral supplements of $8 \mathrm{mg}$ retinol palmitate for a period of 2-3 weeks. After supplementation, levels of haemoglobin, packed cell volume, and serum Fe increased significantly.

Mejia \& Arroyave (1982) evaluated the vitamin A fortification programme of Guatemala, and reported a significant improvement of serurn $\mathrm{Fe}$, and total $\mathrm{Fe}$-binding capacity and a significant fall in serum ferritin. They observed that after 6 months of vitamin A fortification, variables of Fe status had improved. Because the total Fe-binding capacity increased and the levels of serum ferritin declined, it appears that after fortification there was an increase in the availability of serum $\mathrm{Fe}$ due to mobilization of the Fe stores. After 2 years of fortification an overall significant improvement in all $\mathrm{Fe}$ variables was observed: serum Fe, percentage transferrin saturation, and ferritin had increased significantly and total Fe-binding capacity had decreased. The authors concluded that in vitamin A deficiency, stored $\mathrm{Fe}$ is increased and that intervention with vitamin A may affect positively the level of plasma transferrin, which would increase the availability of Fe for haematopoiesis.

Muhilal et al. (1988) conducted a controlled intervention trial with commerciallymarketed monosodium glutamate fortified with vitamin A. They demonstrated a rise in haemoglobin of $10 \mathrm{~g} / \mathrm{l}$ in the supplemented group. In a well-designed study done by Mejia \& Chew (1988) four groups of anaemic children were supplemented for 2 months with vitamin $\mathrm{A}, \mathrm{Fe}$, vitamin $\mathrm{A}$ plus Fe, or a placebo. Vitamin A supplementation produced significant increases in serum levels of retinol and $\mathrm{Fe}$, haemoglobin, packed cell volume, erythrocyte count, and percentage transferrin saturation, but had no effect on total Fe-binding capacity or serum ferritin. The elevation in serum Fe was greater when both vitamin $\mathrm{A}$ and Fe were administered. They concluded that the primary effect of vitamin A supplementation is an increase in serum Fe levels.

In Thailand, Bloem et al. (1989) showed that high-dose vitamin A supplementation of anaemic children resulted in increases in serum $\mathrm{Fe}$ and transferrin saturation after 2 months but not after 4 months. There was no significant change in haemoglobin levels. Seasonal influences, the end of the dry season which apparently led to improvement in the nutritional intake of the control group as well, may have reduced the impact of this experiment. Vitamin A supplementation affected the morbidity in the first 2 months of the trial (Bloem et al. 1990b). To evade this confounding effect, a subsequent study was carried out among non-anaemic children with conjunctival xerosis. This intervention trial resulted in increases in haemoglobin, packed cell volume, serum $\mathrm{Fe}$, and transferrin saturation among the recipients of vitamin A (Bloem et al. 1990a). The authors did not observe any change in morbidity in the intervention group during the 2 week interval.

An intervention trial of 236 preschool children in Indonesia showed that vitamin A 


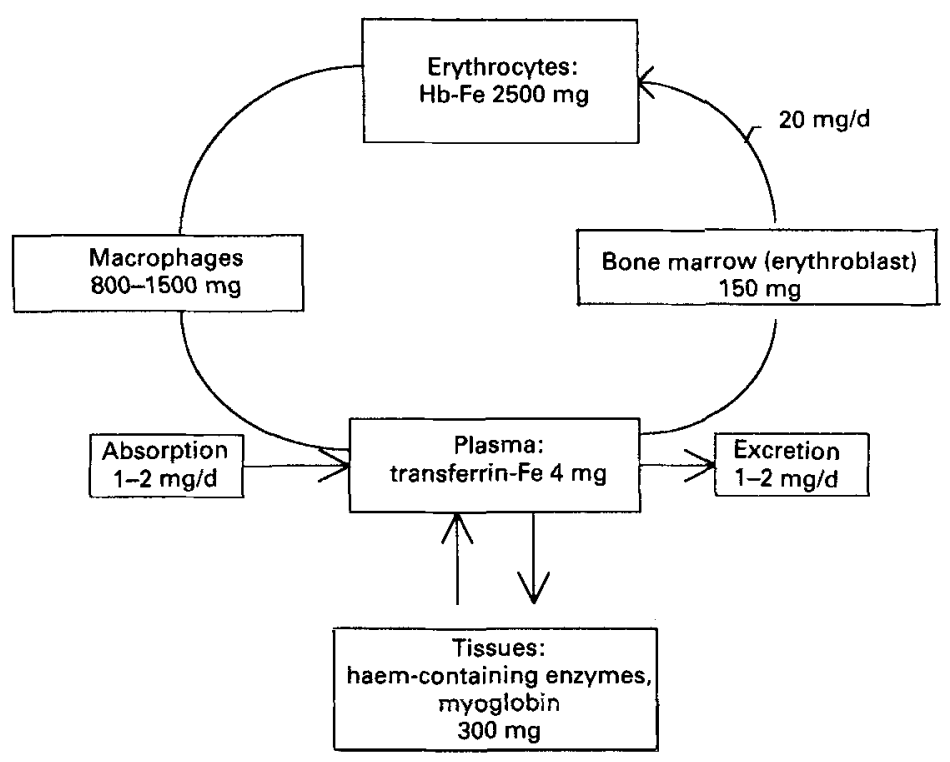

Fig. 1. Iron metabolism. Hb, haemoglobin.

supplementation was associated with a large increase in plasma ferritin, a moderate increase in plasma transthyretin, and an increase in haemoglobin in children with low baseline haemoglobin (Semba et al. 1992). This study was the first which demonstrated a large increase in plasma ferritin levels following vitamin A supplementation. This could be a secondary effect of an improved Fe uptake after re-utilization of Fe stores as a result of the vitamin A supplementation. In the latest intervention study reported, combined vitamin $\mathrm{A}$ and $\mathrm{Fe}$ supplementation in 251 anaemic pregnant women, aged 17-35 years, led to $97 \%$ of the women becoming non-anaemic (Suharno et al. 1993).

\section{DISCUSSION}

Although there is strong evidence for an association between vitamin A and anaemia, the underlying biochemical mechanism is still obscure. Fe-deficiency anaemia develops as the end result of a series of steps that begin with the depletion of stored Fe. The diagnosis of Fe-deficiency anaemia is characterized by a reduced serum Fe level, an increased serum Fe-binding capacity, low mean cell volume, and a reduced serum ferritin level. Anaemia caused by vitamin A deficiency resembles hypochromic anaemia. Unlike in Fe-deficiency anaemia, however, ferritin levels in vitamin A-deficiency anaemia are normal.

$\mathrm{Fe}$ is an essential nutrient, being necessary for haemoglobin formation and for the oxidative processes of living tissues. The body contains about $3-5 \mathrm{~g} \mathrm{Fe}$ of which $65-70 \%$ is present as haemoglobin (Fig. 1). Most of the remainder is present in storage form, either as ferritin or haemosiderin in the reticulo-endothelial system. A further $5 \%$ is present as myoglobin with smaller amounts occurring in haem-containing enzymes or in plasma bound to transferrin. 
Fe is lost from the body in the urine, faeces, nails, hair, skin, and sweat, but the total loss is small $(0.5-1 \mathrm{mg} / \mathrm{d})$. In healthy men and non-menstruating women the loss is replaced by the absorption of about $1 \mathrm{mg} / \mathrm{d}$; about $2 \mathrm{mg}$ needs to be absorbed daily by menstruating women. In pregnancy and lactation $3 \mathrm{mg}$ or more must be absorbed daily.

Fe is absorbed chiefly in the duodenum and jejunum, absorption being aided by the acid secretion of the stomach and being more readily effected when the Fe is in the ferrous state. There are two types of dietary Fe: haem- and non-haem-Fe. In developing countries a small percentage (less than $10 \%$ ) of Fe from food is in the form of haem-Fe, which is derived primarily from the haemoglobin and myoglobin of meat and is well absorbed. The remainder of dietary Fe is in the form of Fe salts and is referred to as non-haem-Fe. The extent to which this type of $\mathrm{Fe}$ is absorbed depends both on the person's Fe status and on the other components of the diet. Only about $10 \%$ of the $\mathrm{Fe}$ ingested in food is normally absorbed. The anaemia associated with vitamin A deficiency is not caused by impaired intestinal absorption of dietary Fe. In fact, some studies showed an increase in Fe absorption as a result of induced vitamin A deficiency (Amine et al. 1970; Beynen et al. 1991; Roodenburg et al. 1994).

The transport $\mathrm{Fe}$ in the serum is bound to a $\beta$-1-globulin known as transferrin. In their fortification evaluation Mejia \& Arroyave (1982) showed that improving vitamin A intake of children resulted in both an increase in serum $\mathrm{Fe}$ and total Fe-binding capacity. They suggested that the lack of vitamin A may directly impair synthesis of transferrin. However, in a subsequent intervention study of Mejia \& Chew (1988) the levels of total Fe-binding capacity remained unchanged despite the increase in serum $\mathrm{Fe}$.

Tomkins (personal communication) observed that vitamin A supplementation always results in an increase in serum $\mathrm{Fe}$ but not always in an increase in haemoglobin levels. This observation supports the hypothesis that the primary effect of vitamin A supplementation is elevation in serum $\mathrm{Fe}$ and that this change may favour haematopoiesis, resulting in an increase in haemoglobin and packed cell volume. Despite the publications of Douer \& Koeffler $(1988 a, b)$ limited information is available on the direct effect of vitamin $\mathrm{A}$ on erythropoiesis. Thus, the most plausible explanation is that vitamin $\mathrm{A}$ deficiency inhibits the re-utilization of Fe for erythropoiesis.

All these possible mechanisms are based on stages in Fe metabolism at which vitamin A deficiency could exert an effect. However, Thurnham (1993) has proposed an interesting possible indirect mechanism (Fig. 2) based on a suggestion of Mejia \& Chew (1988). If micro-organisms penetrate the body then there are a number of anti-microbial agents that can be produced or activated rapidly in response to infection. These agents include lysozyme, acute-phase proteins and the interferons. The acute-phase proteins are a diverse group of proteins, many of which are made by cells of the liver, e.g. C-reactive protein, serum amyloid, orosomucoid, and lactoferrin. Retinol-binding protein and transferrin are 'negative acute-phase proteins', as a consequence of which both retinol and $\mathrm{Fe}$ serum levels will drop during infection.

Furthermore, serum retinol levels may drop during infection because of decreased intake and absorption of dietary vitamin A due to to diarrhoea or intestinal pathogens, accelerated utilization by target tissues, and increased urinary losses of vitamin A (Sommer, 1982; Thurnham \& Singkamani, 1991).

The key element of Thurnham's (1993) hypothesis is the immune properties of vitamin A. Although vitamin A has long been suggested to play a role in immunity to infectious diseases, it has been only in the last decade that epidemiological, immunological, and 


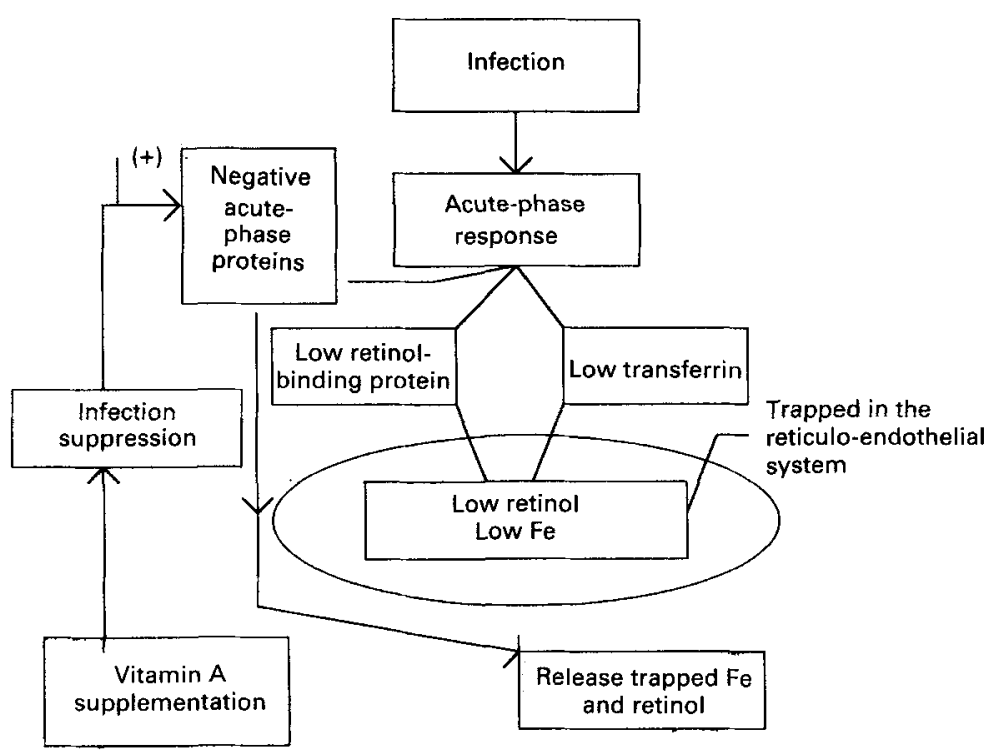

Fig. 2. Interdependence of vitamin A and iron. From Thurnham (1993).

molecular studies have provided substantial evidence for a central role of vitamin $\mathrm{A}$ in immunity (Semba, 1994). Vitamin A supplementation would be expected to suppress infection and stimulate a resumption of transferrin and retinol-binding protein synthesis, thereby releasing the trapped Fe and retinol.

The findings of several studies which indicated that there was no change in morbidity during supplementation in the intervention group would argue against this hypothesis (Bloem et al. 1990a; Suharno et al. 1993; Roodenburg et al. 1994). Thurnham (1993) debated that although clinically there is maybe no detectable infection, mild vitamin A deficiency results in impairment of epithelial integrity of several tissues, particularly the gut. This would allow bacteria which are normally present to invade and colonize. Vitamin A supplementation may be a treatment for these low-grade opportunistic infections. More research is needed to elucidate this hypothesis.

Despite the fact that the biochemical mechanism is still unclear, vitamin A supplementation should play a role in the treatment of anaemia. Although traditionally vitamin A deficiency has been considered to be a problem among preschool children, recent evidence from Bangladesh showed that vitamin A deficiency is widespread among women of reproductive age and the level of nightblindness was as high as among preschool children (Bloem et al. 1994). Vitamin A deficiency in Indonesia is less prevalent than that in Bangladesh and the rest of the Indian subcontinent, and even there vitamin A supplementation alone could reduce anaemia by $35 \%$ in pregnant women.

In conclusion, these findings suggest that programmes designed to reduce anaemia in populations will be more effective when combined with vitamin A supplementation. 


\section{REFERENCES}

Amine, E. K., Corey, J., Hegsted, D. M. \& Hayes, K. C. (1970). Comparative hematology during deficiencies of iron and vitamin A in the rat. Journal of Nutrition 100, 1033-1040.

Beynen, A. C., Sijtsma, K. W., van den Berg, G. J., Lemmens, A. G. \& West, C. E. (1991). Iron metabolism in vitamin A deficiency. Trace Elements in Man and Animals 7, 215-216.

Blackfan, K. D. \& Wolbach, S. B. (1933). Vitamin A deficiency in infants. Journal of Pediatrics 3, 679-706.

Bloem, M. W., Huq, N. \& Matzger, H. (1994). Vitamin A deficiency among women in the reproductive years: an ignored problem. XVI IVACG Meeting 1994. Proceedings of the International Vitamin A Consultative Group. Washington: IVACG.

Bloem, M. W., Wedel, M., Egger, R. J., Speek, A. J., Schrijver, J., Saowakontha, S. \& Schreurs, W. H. P. (1989). Iron metabolism and vitamin A deficiency in children in northeastern Thailand. American Journal of Clinical Nutrition 50, 332-338.

Bloem, M. W., Wedel, M., Egger, R. J., Speek, A. J., Schrijver, J., Saowakontha, S. \& Schreurs, W. H. P. (1990b). Mild vitamin A deficiency and risk of respiratory tract diseases and diarrhea in preschool and school children in northeastern Thailand. American Journal of Epidemiology 131, 332-339.

Bloem, M. W., Wedel, M., van Agtmaal, E. J., Speek, A. J., Saowakontha, S. \& Schreurs, W. H. P. (1990a). Vitamin A intervention: short-term effects of a single, oral, massive dose of vitamin A on iron metabolism. American Journal of Clinical Nutrition 51, 76-79.

Corey, J. E. \& Hayes, K. C. (1972). Cerebrospinal fluid pressure, growth and hematology in relation to retinol status of the rat in acute vitamin A deficiency. Journal of Nutrition 102, 1585-1594.

Douer, D. \& Koeffler, H. P. (1982a). Retinoic acid enhances growth of human early erythroid progenitor cells in vitro. Journal of Clinical Investigation 69, 1039-1041.

Douer, D. \& Koeffler, H. P. (1982b). Retinoic acid enhances colony-stimulating factor induced clonal growth of normal human myeloid progenitor cells in vitro. Experimental Cell Research 138, 193-198.

Findlay, G. M. \& MacKenzie, R. D. (1922). The bone marrow in deficiency diseases. Journal of Pathology 25, $402-403$.

Food and Agriculture Organization/World Health Organization (1992). Final Report of the International Conference of Nutrition, pp. 43-55. Rome: FAO

Hodges, R. E., Sauberlich, H. E., Canham, J. E., Wallace, D. L., Rucker, R. B., Mejia, L. A. \& Mohanram, M. (1978). Hematopoietic studies in vitamin A deficiency. American Journal of Clinical Nutrition 31, $876-885$

Humphrey, J. H., West, K. P. \& Sommer, A. (1992). Vitamin A deficiency and attributable mortality among under-5-year-olds. Bulletin of the World Health Organization 70, 225-232.

Koessler, K. K., Maurer, S. \& Loughlin, R. (1926). The relation of anemia, primary and secondary, to vitamin A deficiency. Journal of the American Medical Association 87, 476-482.

McLaren, D. S., Tchalian, M. \& Ajans, Z. A. (1965). Biochemical and hematological changes in the vitamin A deficient rat. American Journal of Clinical Nutrition 17, 131-138.

Mahant, L. \& Eaton, H. D. (1976). Effect of chronic hypovitaminosis A on water metabolism in the weanling rat. Journal of Nutrition 106, 1817-1826.

Mejia, L. A. \& Arroyave, G. (1982). The effect of vitamin A fortification of sugar on iron metabolism in preschool children in Guatemala. American Journal of Clinical Nutrition 36, 87-93.

Mejia, L. A. \& Chew, F. (1988). Hematological effect of supplementing anemic children with vitamin A alone and in combination with iron. American Journal of Clinical Nutrition 48, 595-600.

Mejia, L. A., Hodges, R. E., Arroyave, G., Viteri, F. \& Torun, B. (1977). Vitamin A deficiency and anemia in Central American children. American Journal of Clinical Nutrition 30, 1175-1184.

Mejia, L. A., Hodges, R. E. \& Rucker, R. B. (1979a). Clinical signs of anemia in vitamin A-deficient rats. American Journal of Clinical Nutrition 32, 1439-1444.

Mejia, L. A., Hodges, R. E. \& Rucker, R. B. (1979b). Role of vitamin A in the absorption, retention and distribution of iron in the rat. Journal of Nutrition 109, 129-137.

Mohanram, M., Kulkarni, K. A. \& Reddy, V. (1977). Hematological studies in vitamin A-deficient children. International Journal of Vitamin and Nutrition Research 47, 389-393.

Muhilal, Permeisih, D., Idjradinata, Y. R., Muherdiyantiningsih \& Karyadi, D. (1988). Vitamin A-fortified monosodium glutamate and health, growth, and survival of children: a controlled field trial. American Journal of Clinical Nutrition 48, 1271-1276.

Roodenburg, A. J. C., West, C. E., Hovenier, R. \& Beynen, A. C. (1996). Supplemental vitamin A enhances the recovery from iron deficiency in rats with chronic vitamin A deficiency. British Journal of Nutrition (In the Press). 
Roodenburg, A. J. C., West, C. E., Yu, S. \& Beynen, A. C. (1994). Comparison between time-dependent changes in iron metabolism of rats as induced by marginal deficiency of either vitamin $\mathrm{A}$ or iron. British Journal of Nutrition 71, 687-699.

Semba, R. D. (1994). Vitamin A, immunity, and infection. Clinical Infectious Diseases 19, 489-499.

Semba, R. D., Muhilal, West, K. P. Jr., Winget, M., Natadisastra, G., Scott, A. \& Sommer, A. (1992). Impact of vitamin A supplementation on hematological indicators of iron metabolism and protein status in children. Nutrition Research 12, 469-478.

Sommer, A. (1982). Nutritional Blindness. New York: Oxford University Press.

Staab, D. B., Hodges, R. E., Metkalf, W. K. \& Smith, J. L. (1984). Relationship between vitamin A and iron in the liver. Journal of Nutrition 114, 840-844.

Suharno, D., West, C. E., Muhilal, Karyadi, D. \& Hautvast, J. G. A. J. (1992). Supplementation with vitamin $A$ and iron for nutritional anemia in pregnant women in West Java, Indonesia. Lancet 342, 1325-1328.

Suharno, D., West, C. E., Muhilal, Logman, M. H. G. M., de Waart, F. G., Karyadi, D. \& Hautvast, J. G. A. J. (1992). Cross sectional study on the iron and vitamin A status of pregnant women in West Java, Indonesia. American Journal of Clinical Nutrition 56, 988-993.

Sure, B., Kirk, M. C. \& Walker, D. J. (1929). The effect of avitaminosis on hematopoietic function. Journal of Biological Chemistry 83, 375-408.

Thurnham, D. I. (1993). Vitamin A, iron, and haemopoiesis (editorial). Lancet 342, 1312-1313.

Thurnham, D. I. \& Singkamani, R. (1991). The acute phase response and vitamin A status in malaria. Transactions of the Royal Society of Tropical Medicine and Hygiene 80, 603-612.

United Nations Administrative Committee on Coordination/Subcommittee on Nutrition (1992). Second Report on the World Nutrition Situation. Geneva: ACC/SCN.

Wagner, K. H. (1940). Die Experimentell Avitaminose A beim Menschen (Experimental avitaminosis in humans). Hoppe-Seyler's Zeitschrift für Physiologishe Chemie 246, 153-189.

Wolbach, S. B. \& Howe, P. R. (1925). Tissue changes following deprivation of fat-soluble A vitamin. Journal of Experimental Medicine 42, 753-777.

Wolde-Gebriel, Z., West, C. E., Haile Gebru, Tadesse, A. S., Fisseha, T., Gabre, P., Aboye, C., Ayana, G. \& Hautvast, J. G. A. J. (1993). Interrelationship between vitamin A, iodine and iron status in school children in Shoa Region, Central Ethiopia. British Journal of Nutrition 70, 593-607. 